\title{
Using Future Scenario Planning as a tool for informed decision making on infrastructure interventions in Kibera, Nairobi in Kenya
}

Margarita Garfias Royo*, Priti Parikh*, Franklin Mutwiri†, Jamilla Harper ${ }^{\dagger}$, Vera Bukachi†\& Joe Mulligan $^{\dagger}$

* Civil, Environmental and Geomatic Engineering, University College London, UK

${ }^{\dagger}$ Kounkuey Design Initiative, Nairobi, Kenya

Keywords: Kibera; Scenario Planning; Flooding; Flood mitigation; Infrastructure; Assets.

\begin{abstract}
This paper focuses on the use of Future Scenario Planning and an adaptation of the Sustainable Livelihoods Framework as analysis tools for informed decision-making in a community workshop. The aim of this methodology was to assess the perceived impacts of two infrastructure interventions for flood mitigation (local drainage improvement and local flood protection by gabions along the river edges) in the Andolo community in Kibera, Nairobi, in Kenya. Future Scenario Planning was used as a visualisation method for the changes each intervention could bring to the community and the perceived impacts were measured using the assets component of the British Department for International Development (DFID)'s Sustainable Livelihoods Framework. The exercise was delivered as a two-day workshop, which ensured community engagement and facilitated co-decision making of an infrastructure intervention. The process was helpful to ensure sustainability in the use and maintenance of a public space, as well as for initiating conversations within the community regarding critical infrastructure and prioritisation of interventions for mitigating immediate risks.
\end{abstract}

\section{Introduction}

Regional climate change can pose severe risks - which include water-related diseases, destruction of property and death - for poor urban-dwellers, who are disproportionally affected by its impacts (Mulligan et al., 2016; Thorn et al., 2015). Rapid urbanization and global climate change are likely to aggravate these risks, as extreme rainfall events are projected to increase (Mitra et al., 2017; Latif et al., 2015). Residents of Kibera, Nairobi's largest informal settlement, face flooding risks on a biannual basis; a risk which is compounded by poor drainage and solid waste management, and which has become the greatest natural 
hazard faced by the city (BuroHappold Engineering, 2017a; Juma, 2017; Mitra et al., 2017; Mulligan et al., 2017).

Kounkuey Design Initiative (KDI) is a Non-Governmental Organization (NGO) that works with residents of impoverished communities to develop, design and create low-cost, high-impact built environments (Productive Public Spaces; KDI, 2016). In Kibera, they mainly collaborate with established Community Based Organisations (CBOs), to co-produce projects and provide support for long term maintenance and operation. During 2015 and 2016, the main focus of the organisation was to build resilience in communities of Kibera to better respond and adapt to flooding (Mulligan et al., 2015). KDI collaborated with the Water Team from BuroHappold Engineering to create a tool for mapping the flooding extents in Kibera (Mulligan et al., 2017; BuroHappold Engineering, 2017b). Through this tool, Andolo was identified as one of the most vulnerable communities to flood impacts within Kibera. The organisation held several workshops with the community to express their research findings and investigate specific challenges this community faced, in order to identify infrastructural needs as well as to identify a suitable location for the delivery of a public space.

This paper focuses on a tool for participatory informed decision-making which enabled members of Andolo community to identify immediate infrastructural needs in order to select appropriate infrastructure measures to tackle flooding in their community. These aims were served through a methodology which combined Future Scenario Planning with the Sustainable Livelihoods Framework of DFID. The novelty of this decision making tool is that the participating community members defined the framework against which their current situation, and each proposed intervention was assessed, in order to decide which intervention would benefit them the most.

\subsection{Context}

Kibera is located on a hill approximately $5 \mathrm{~km}$ away from the central business district of Nairobi, Kenya's capital (see figure 1; Map Kibera Project, 2010). The settlement is adjacent to the Ngong River and its tributaries, and is subdivided in 13 villages $^{1}$ that cover 225 hectares (Mitra et al., 2017; Mulligan et al., 2016; Guillet, 2014). It is considered among the most insecure, unsanitary and dense slums of East Africa (Skilling \& Rogers, 2017). The estimated population ranges from 235,000 to 270,000, and an estimated 30,000 people live within 30m of the main watercourses (Mulligan et al., 2016; Map Kibera Project, 2010).

\footnotetext{
${ }^{1}$ These villages are Soweto East, Soweto West, Kisumi Ndogo, Kianda, Gatwekera, Silanga, Makina, Lindi, Raila, Mashimoni, Kambi Muru Laini Saba and Mugomoini (Guillet, 2014).
} 
Land tenure security in Kibera is non-existent, rents range from informal rental to squatting, and the threat of eviction is a constant reality (Guillet, 2014; Umande Trust et al., 2007). Dwellings are semi-permanent and host an average of 5 people per household (Umande Trust et al., 2007). Basic infrastructure and services - such as storm water drainage, surfaced roads and footpaths, waste collection systems, electricity supply, and street lighting - are generally insufficient or lacking (Croning \& Guthrie, 2011; Muthoni Kagiri, 2008).

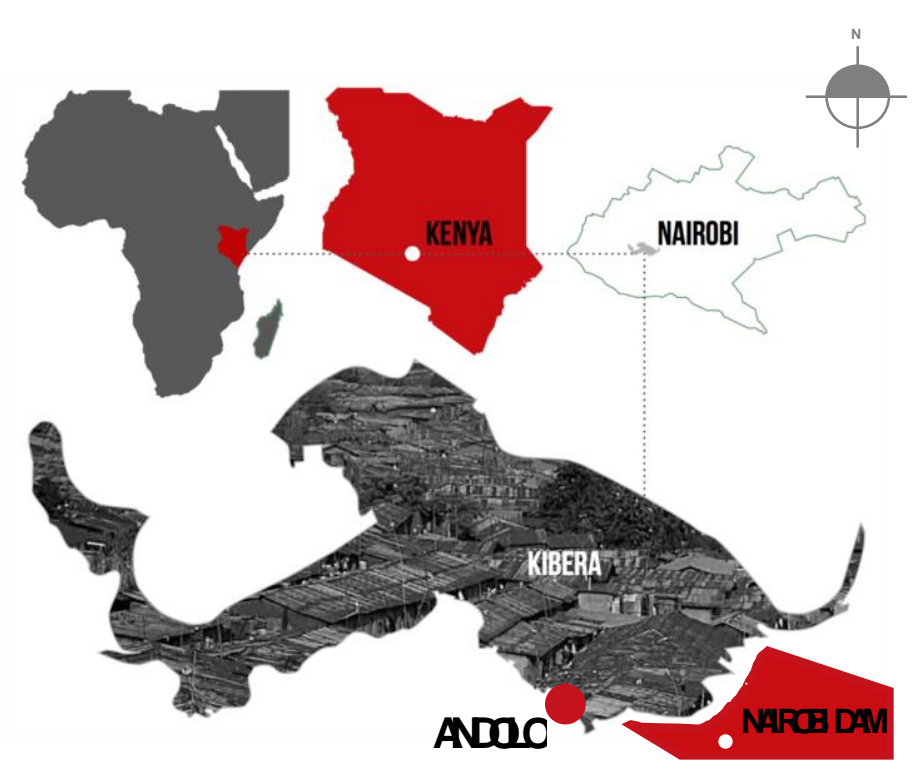

Figure 1. Map of Kibera and location within Nairobi, Kenya. (Source: KDI, 2016, with adaptations from the authors).

Andolo is a community of Lindi village, located along the flood plain of Ngong River in the South East of Kibera, upstream from Nairobi dam. The community has reclaimed land by altering the river's path (see figure 2), which has put it at high risk of flooding, both from the Ngong River and surface water runoff that overtops the informal drainage channels. It was identified by KDI as hosting some of the newest settlers of Kibera (see figures 3 and 4), as it offers some of the lowest rents. Access to Andolo is challenging and it is estimated to have the highest rates of crime, insecurity and under-employment of Kibera (Mulligan et al., 2017; KDI, personal communication, June 26, 2016). As of 2016, the community was relatively new, less established and with low social ties, which posed a threat to social cohesion (Harper, personal communication, June 26, 2016).

There is a lack of information about the area. At the time of this study, there was no official sociodemographic data, no other NGOs working with the community, nor any CBO registered with the Government of Kenya in the immediate community of Andolo (KDI, personal communication, June 26, 
2016). In March 2016, KDI held initial workshops with the residents of Andolo to further explore the challenges the community experiences. These workshops, combined with the survey, showed high levels of riverine and drainage flooding that damages structures, bridges and access ways (see figure 3); lack of sanitation; public health issues such as flood-related injuries, diarrhoea reported among $31 \%$ of children and cholera reported in four households; inadequate access to services; and insecurity, crime and underemployment (KDI, personal communication, June 26, 2016). Despite these challenges, KDI determined that the community had potential to collaborate based on its responsiveness to household level challenges through the Nyumba Kumi Initiative².

2009 - ANDOLO

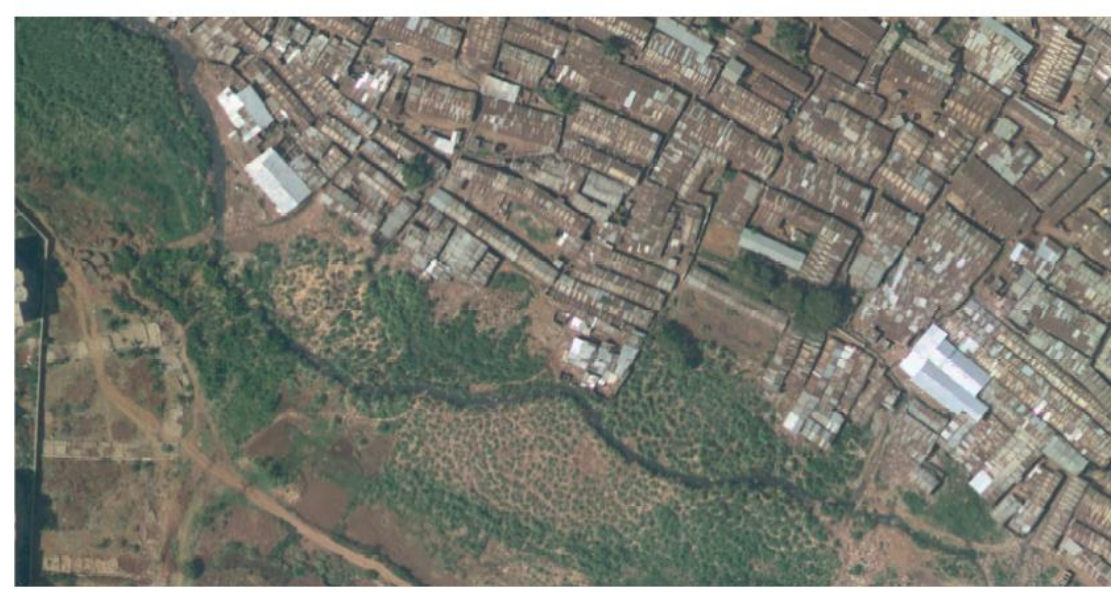

2015 - ANDOLO

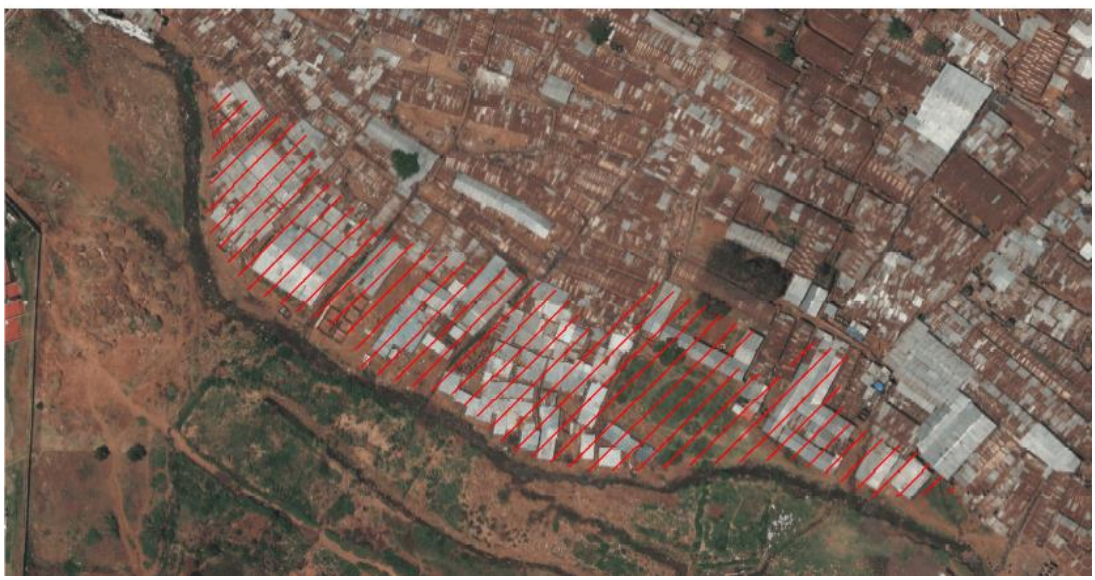

Figure 2. Aerial images of Andolo in 2009 (top) and 2015 (bottom), illustrating the riparian area occupied by new structures. (Source: Wandera, 2016).

\footnotetext{
${ }^{2}$ Nyumba Kumi Initiative was introduced by the Government of Kenya as a community policing strategy at household level with the aim of achieving safe, sustainable neighbourhoods (Otieno Andhoga \& Mavole, 2017; Leting, 2017). In Andolo, it is also used an informal system of organisation in which a group of households associate to create social ties and provide social support, i.e. raising funds to help families within the group to cope with challenges (KDI, personal communication, June 26, 2016).
} 


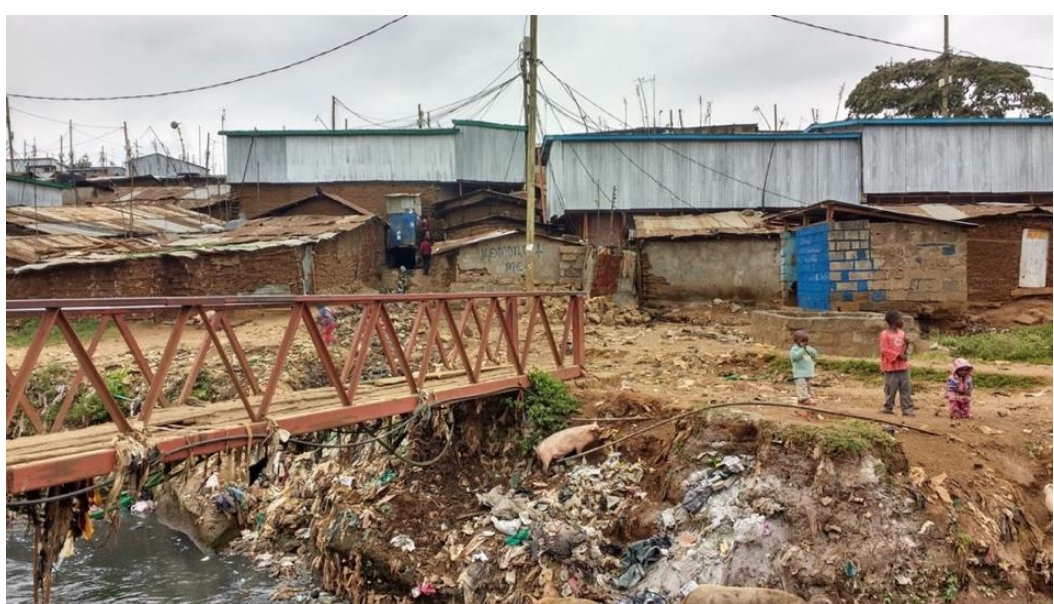

Figure 3. Andolo open space as of July 2016. (Photo by Margarita Garfias Royo).

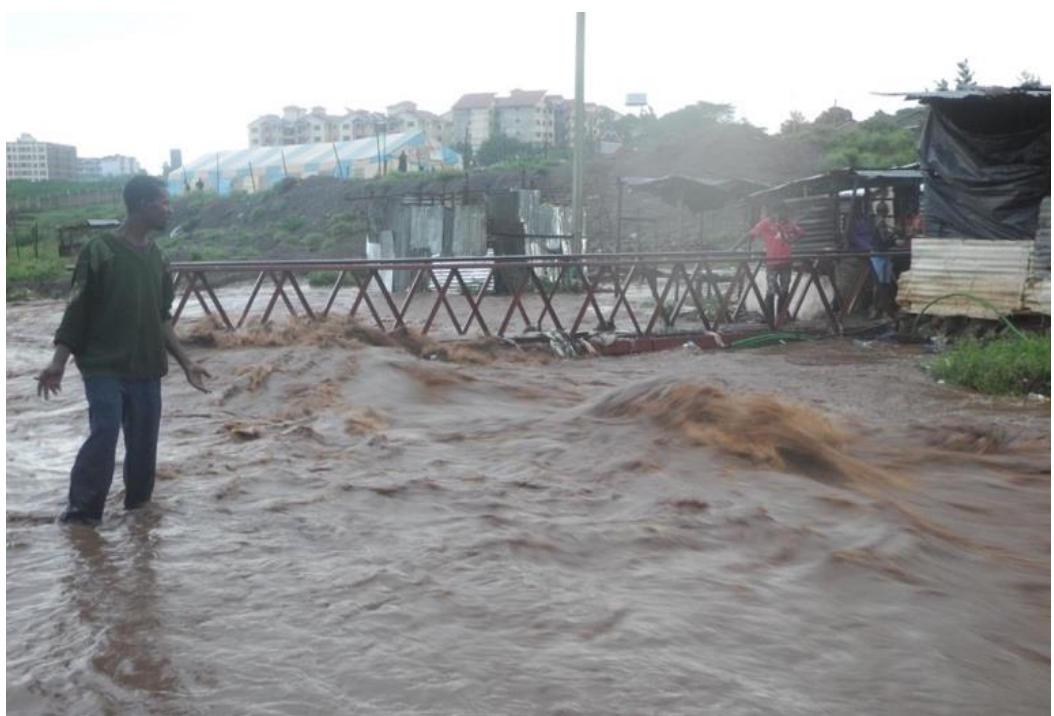

Figure 4. Andolo Bridge flooded at after a 30-minute rain on May 2016. (Photo by Pascal Kipkemboi. Source: Wandera, 2016).

\subsection{Literature review}

There are significant benefits from adopting infrastructure development strategies that include the participation of informal settlement dwellers, especially from those that promote local economic development and mainstream employment-intensive approaches (Majale, 2008). This participation can enable communities to make informed choices and decisions, as residents have access to information and the outcomes of an intervention are clear and transparent (Donovan, 2010; Davidson et al., 2001). The conditions necessary for successful community-based projects include outlining clear boundaries of roles and responsibilities of all the stakeholders, for the facilitating agency to act as a supporting entity in lieu of 
a project manager, and training programmes embedded within the process of engagement (Cotton \& Franceys, 1994). In addition, communities play an effective role in delivering, operating and maintaining basic urban infrastructure (Majale, 2008). Specifically in relation to Kibera, there is evidence to suggest the need for strong engagement with the community members at the outset of slum upgrading programmes to ensure participation during implementation (Meredith \& MacDonald, 2017; Cronin \& Guthrie, 2011). Infrastructure interventions can potentially lead to positive outcomes in informal settlements if the interventions meet the needs and priorities of local residents. (Parikh et al., 2012). In light of this, the authors developed a novel participatory approach for decision making on infrastructure provision, which incorporates Future Scenario Planning and the Sustainable Livelihood Framework as described below.

\subsubsection{Future Scenario Planning (FSP)}

Future scenario planning (FSP) is an exploratory tool for conceiving different futures, or scenarios, and their plausible outcomes (Oppenheimer, 2016; Lienert et al., 2014; Lindgren \& Banhold, 2003). It can be used for conceptualising outcomes that result from taking different approaches to the same initial event, and can be useful for medium and long term planning of future uncertainties (Banhold, 2003; Ringland, 1998). FSP can be of help in understanding the logic of events and assist in exploring a wider range of possible outcomes that could occur quicker than expected (Roxburgh, 2009). Developing scenarios can be useful for generating deeper insights into the underlying drivers of change as well as identifying previously overlooked ones, in addition to supporting the identification of key players, key factors and driving forces that could exert influence (Roxburgh, 2009).

FSP has been amply used by business strategists since the 1960s, and the most notable example is the Shell case (Roxburgh, 2009; Ringland, 1998; Wack, 1985). However, in more recent years, it has been further used in tourism forecasts (Page et al., 2010), environmental studies (Swart et al, 2004; Peterson et al. 2003), strategic planning for urban water infrastructure (Dong et al., 2013; Dominguez et al., 2011; Truffer et al., 2010; Lienert et al., 2006) and urban planning strategies aiming to inform land use and infrastructure investment policies (CMM, 2014 \& 2015; Calthorpe Associates, 2011). Another notable example was in South Africa in 1992, to debate the plausible futures in the post-apartheid transition, known as the Mont Fleur Scenario Exercise (Reos Partners, 2010; Kahane, 1996).

In the development context, FSP has been used for developing climate change and adaptation scenarios (ASSAR, 2017; McSweeney et al., 2010), as well as used as a part of the Rockefeller Foundation's Informal City Dialogues Project (Forum for the Future, 2013). This project focused in exploring the role of the 
informal sector - which included housing, economies and systems - in fostering inclusion and building resilience in six different cities of the Global South, including Nairobi, to create different scenarios aiming to understand and explore the different paths the informal parts of these cities could take and to plan accordingly (Rosen, 2013). Future scenarios have been used in the African Environmental Outlook (AEO) assessment to monitor environmental management and sustainable development in Africa (GRID Arendal, 2017). In these reports future scenarios for Africa are explored and used to provide recommendations for policy action (Foresight for Development, 2017; UNEP, 2005).

The main criticism FSP has faced is its lack of clear methods or steps for building scenarios and theoretical foundations, as it has not been well documented as a process or discipline, regardless of having practical applications (Scearce \& Fulton, 2004). There is no clear evaluation system for measuring the impact of scenario planning, as it can be used in a vast array of disciplines that differ vastly from one another. Furthermore, it is a long-term envisioning tool that may not be useful for solving immediate pressures. Given the nature of the tool, its application in a strategy-creation setting requires the participants to be motivated, involved and in good disposition to learn - otherwise the probability of the tool being ineffective increases (Scearce \& Fulton, 2004; Chermack et al., 2001).

\subsubsection{Sustainable Livelihoods Framework (SLF)}

A livelihood could be defined as the capability and activities people perform to sustain and secure their means of living (IFRC, 2016; Chambers \& Conway, 1991). The Sustainable Livelihoods Framework (SLF) is used in the analysis of people's access to resources, specifically those which directly influence diversity in livelihood, as livelihood creation is seen to be a strong determinant of poverty (Adato \& Meinzen-Dick, 2002). It was developed by the DFID for planning and management as an ordered approach to complexity to provide structure to the many factors, and their interactions, that affect livelihoods (ATHA, 2014; DFID, 1999a). According to the DFID (1999b), the aim of the framework is to advise stakeholders in decision making, planning and execution so that the quality and performance of their development activities improve. The framework was designed as a participatory tool in order to integrate the analysis of policies and institutions with community-level analysis (Carney, 1999). It comprises five interrelated components influenced by internal and external dynamics, which include: vulnerability context, livelihood assets, transforming structures and processes, livelihood strategies and livelihood outcomes (see figure 5; ATHA, 2014; van Rijn et al., 2012; Adato \& Meinzen-Dick, 2002; DFID, 1996b). 


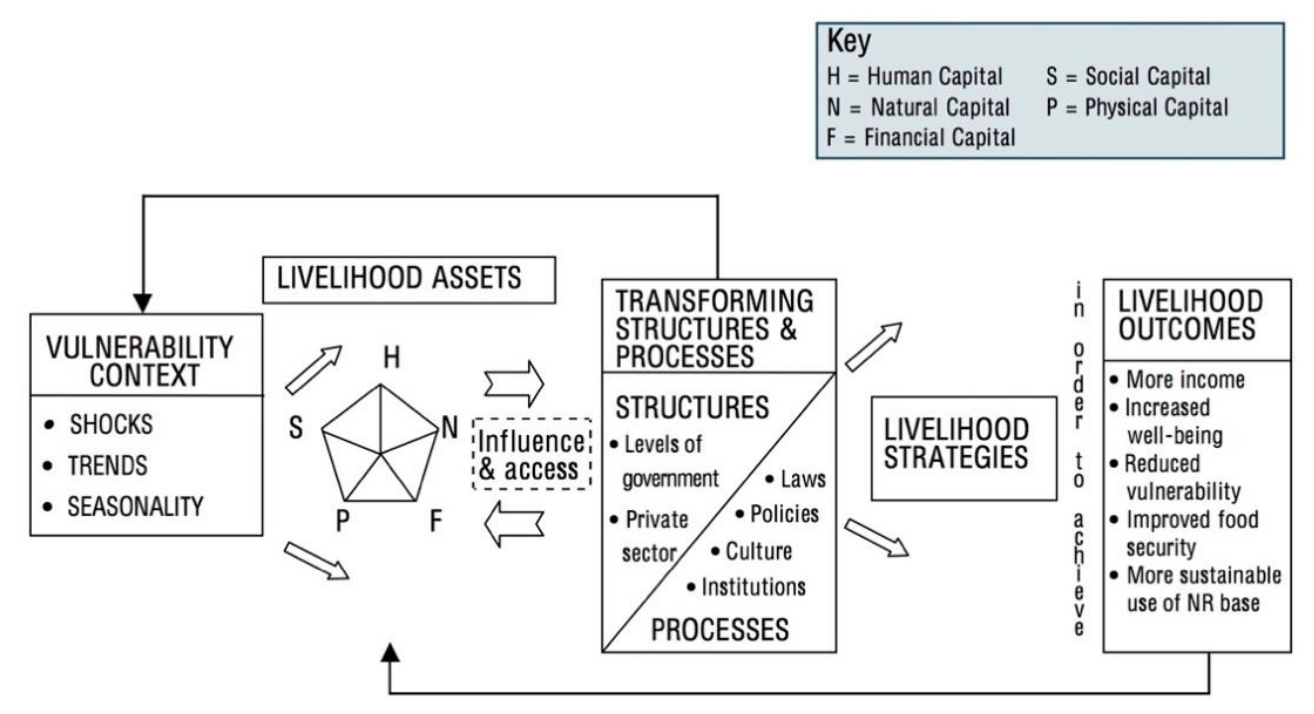

Figure 5. Explanatory figure of the Sustainable Livelihoods Framework. (Source: DFIDa, 1999).

In the development setting, the framework has been adapted by Hagans (2013) to identify needs of the urban poor in Nairobi in terms of accessibility and how the city's planning responds to them. Van Rijn et al. (2012) applied the framework to conduct a socio-economic impact assessment study for the DE Foundation coffee support project in Peru. The framework has been widely used and adapted for several studies in different areas. These range from aiming to understand the urban poor's livelihood strategies in different cities around the world, including Kampala, Dhaka City, Kolkata and Malawi, among others (Chaudhuri, 2013; Dimanin, 2012; Hossain, 2005; Orr \& Mwale, 2001); assess climate change vulnerability and adaptation (Pandey et al., 2017; Mersha, \& Van Laerhoven, 2016; Hahn et al., 2009); study natural resources management (Orchard et al., 2016); understand the link between tourism and local livelihoods (Qian et al., 2017; Lee, 2008); and understand the nexus between poverty and HIV/AIDS (Masanjala, 2007). Asset based indicators have also been used to assess resilience of informal settlement communities in Kibera (Woolf et al., 2016).

The framework however has faced some criticisms. According to Meikle et al. (2001) and Farrington et al. (2002), much of the work carried out on livelihood assets has been set in rural contexts. Meikle et al. (2001) argue that while the principles underlying the livelihoods approach apply to both rural and urban settings, there are contextual differences between these areas, as well as among urban areas. Meikle et al (2001) present a sustainable urban livelihoods model and its policy and practical implications for urban development interventions. Dakson and Binns (2010) believe that the framework does not fully consider and address cultural values and the role of cultural beliefs in livelihood creation. 
Alternatively, Scoones (1998) suggests that the different criteria and concepts that the SLF comprises may contest with one another, and that the first step in the intervention process should be negotiating the definition of a sustainable livelihood among the stakeholders. Under this criticism, following the framework definitions may conflict with the understanding of a specific audience. Moreover, the work involved to carry out the SLF methodology is quite resource intensive, regardless of the scale of its application (Morse et al., 2009). The willingness of the participants to provide information, not to mention its quality and quantity, is always unknown (ibid).

\section{Method}

The workshop in Andolo, which is the focus of this paper, was designed during the first half of July 2016. KDI had previously identified key stakeholders directly concerned with the selected area where the intervention would take place. This was done through a series of workshops held with the community during the previous months, ${ }^{3}$ as well as with the selection of a specific site location. The direct stakeholders of the intervention included the tenants of the neighbouring structures of the selected site, as well as the structure owners. An external ethical review process was overseen by the UCL Chair of Ethics, who provided approval for carrying out community meetings in Kibera in Nairobi, Kenya.

Recruitment of participants and dissemination of the workshop was done verbally at the end of the previous workshop held by KDI with the community on July 16, 2016, in which talks regarding the formalisation of a Community Based Organisation were held. It was also reiterated in a short meeting held between the elders of the community and the researchers - after wrapping up the July 16 session — to circulate the workshop with the residents. Informative posters were put up in doors in the surrounding area, in which it was suggested for at least two members of each structure neighbouring the selected site to attend the workshop, regardless of their age, gender, race, religion, income or occupation. There were no specifications on the number of participants needed in the workshop, as the priority was to call any members of Andolo community neighbouring the selected site to participate if available on the day.

\subsection{Workshop Design}

The workshop was designed to develop scenarios for different types of infrastructure interventions in order to assess the perception of the participants regarding the impacts on their livelihoods. It was designed to be

\footnotetext{
${ }^{3}$ In these workshops, KDI sought to explore ways of communicating flood risks (Ideo, 2016), as well as selecting a specific location (KDI, personal communication, June 26, 2016).
} 
delivered as participatory, sequential exercises. In each exercise, participants were asked to share ideas, provide comments and agree by voting ${ }^{4}$ on meanings. All the exercises of the workshop were carried out a big, single group. The workshop programme comprised the following five stages (see figure 6), intended to be carried out in two sessions of four hours each (steps 1 to 3 in the first session and steps 4 and 5 in the second session):
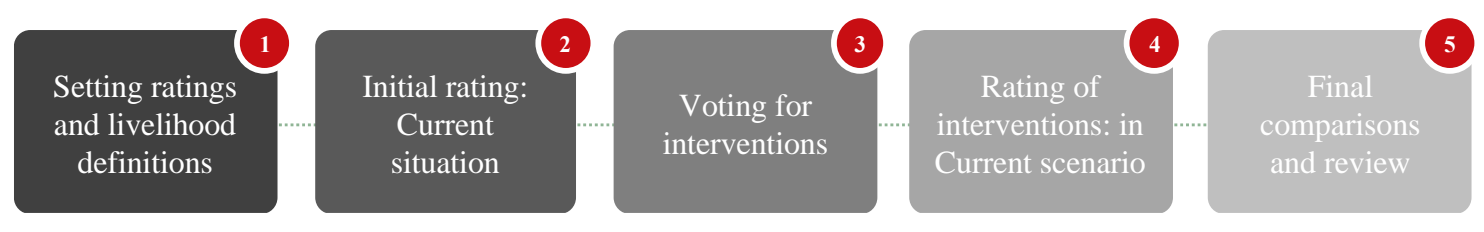

Figure 6. Workshop stages.

\section{1) Setting Definitions}

The first stage comprised presenting the assets pentagon of the SLF to the participants and introduce each asset (Human, Natural, Financial, Physical and Social) as a different component of a livelihood-it is important to note that no definitions were provided in this introduction (see figure 7). The facilitators then guided the discussion for the participants to define what each asset meant to them. The discussion was guided by prompting ideas based on the SLF's proposed definition for each asset (see table 1 for the definitions), which were not provided directly to the participants. Participants were asked to contribute with definitions and discuss on the most appropriate meaning, and a final definition was decided through simple majority voting. This process was intended to tailor the definitions to the context, avoid misunderstandings in the following exercises, and diminish the possibility of future disagreements with KDI in later stages of the intervention.

Following the definition of assets, a rating guide was developed for each asset. Participants were asked to think of what 'good' and 'bad' represented for each asset, and then to further categorise it ranging from 0 (very bad or non-existent) to 5 (very good). Definitions were again discussed among participants and decided through simple majority voting. See Appendix A for the rating guide.

\footnotetext{
${ }^{4}$ Voting was made by simple majority by raising hands until half or more of the participants had raised their hand. If any participant did not raise their hand, they were asked if they had any contributing comments on the definitions, and the process was repeated.
} 


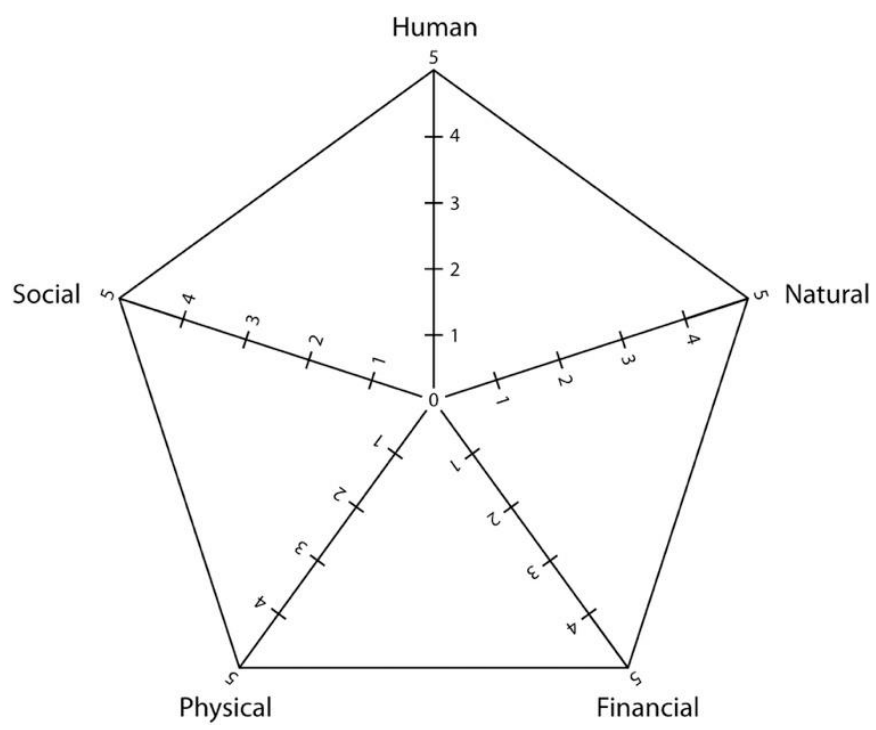

Figure 7. SFL's assets component pentagon.

Table 1. Meaning of the assets of the SLF as defined by the DFID's framework (DFID, 1999b).

\begin{tabular}{c|l} 
Capital & \multicolumn{1}{|c}{ Meaning as defined by the DFID's framework } \\
\hline Human & $\begin{array}{l}\text { Skills, knowledge, ability to labour and good health that together enable } \\
\text { people to pursue different livelihood strategies and achieve their livelihood } \\
\text { objectives. }\end{array}$ \\
\hline Natural & $\begin{array}{l}\text { Natural resource stocks from which resource flows and services (e.g. } \\
\text { nutrient cycling, erosion protection) useful for livelihoods. }\end{array}$ \\
\hline Financial & Financial resources that people use to achieve their livelihood objectives. \\
\hline Physical & Basic infrastructure and producer goods needed to support livelihoods. \\
\hline Social & $\begin{array}{l}\text { The social resources upon which people draw in pursuit of their livelihood } \\
\text { objectives, such as networks and connectedness, membership to formalised } \\
\text { groups and relationships of trust. }\end{array}$
\end{tabular}

2) Initial rating: Their Current Situation

The participants then rated their current situation in relation to each asset according to the agreed rating guide. The participants were asked to comment on, explain and discuss their proposed ratings, again reaching a consensus through simple majority voting. The arguments for the selected rating for each asset were recorded. Each asset represents a corner of the pentagon; when all the assets were rated, a participant was asked to the front to 'plot' the pentagon in a cardboard using rope and tacks.

3) Voting For Interventions 
The plotted pentagon, which reflected how the participants rated each asset, was used for quick visual analysis. Based on this analysis, and after recapitulating what each rating meant, the participants were then presented with a list of plausible interventions and asked to vote on the two interventions they considered would have the most substantial impact in all the presented assets, aiming to create a wider polygon, preferably touching all the corners. Each participant voted for two interventions by placing one sticker next to their two choices. The voting was made by providing each participant with a ballot containing a list of the interventions, and were asked to keep their vote secret. The two interventions with the most votes would be assessed in the next session of the workshop therefore it was agreed that any ballot containing more or less than two stickers was considered void.

The interventions to assess were determined by the authors based on preliminary discussions with the wider community of Andolo and the selected location's constraints and technical needs, as identified by KDI. All the participants of the workshop were aware of the plausible infrastructure interventions, as they had been part of former workshops and conversations held in collaboration between KDI and the wider community. The list of interventions to evaluate was the following:

\section{Local Drainage Improvement}

2. Local River Protection

3. Water Collection Point

4. Local Solid Waste Management

5. Toilet Block

6. Local Sewer Improvement

7. Local Flood Protection

8. Better Access to Bridge

9. Improvement of Local Pathways

Discussions on including lighting and power of the area were held. However, it was decided to exclude these services due to the political, economic and technical constraints of the area, as well falling outside the scope, capabilities and advocacy of $\mathrm{KDI}^{5}$. Furthermore, KDI was careful of igniting false hopes among the community about receiving these services.

\footnotetext{
${ }^{5}$ Andolo is located between two transformers, therefore it is not connected to the electric grid (stima), as it represents a challenge for the electric company and local authorities to make a connection. Moreover, Andolo's residents are currently unable to afford the initial capital needed to obtain off-grid systems.
} 


\section{4) Rating of Interventions: In Current Scenario}

The top two interventions with the most votes were assessed based on the agreed definitions of the assets and their corresponding ratings, in the same manner their current situation was evaluated. The impact of both interventions were analysed in relation to the current situation, as if they had been newly implemented. The assessment also included a question about perceived ease of maintenance after the delivery of the project, to introduce the concepts of ownership and management regarding the future conditions of the selected infrastructure intervention. The assessment of the second intervention was led by two participants, and the facilitators only provided assistance in the process.

\section{5) Final Comparisons and Review}

The workshop was closed by presenting the results of all the ratings next to each other and comparing them. The bigger the pentagons, the better rated and the more impact the intervention could have. Upon these results, the participants agreed on and chose one intervention to be designed and carried out in collaboration with KDI.

\subsection{Workshop facilitation}

There were two facilitators: a member of KDI, who spoke both Swahili and English, and an external researcher, who only spoke English. The KDI member was trained in the delivery of the workshop and instructed about the activities to be carried out, in order to deliver similar future workshops with different communities throughout Kibera. This facilitator had engaged in previous workshops and talks with the community, so had more knowledge of the area and the community. This facilitator was also in charge of the design of a public space for the area. The external researcher was responsible for the design of the workshop. This facilitator was only briefed on the technical characteristics and needs of the selected area, and had only visited the area once and met few members of the community in a previous meeting before the workshop.

Two preliminary meetings were held - one with other members of KDI, and one between the two facilitators - to discuss the activities of the workshop, including training on both FSP and SLF, and to negotiate the tone in which the activities needed to be delivered in order to be fully understood by the participants (such as talking in lay person language and keeping terms concise and simple). 


\section{Results}

The workshop took place in the late morning and early afternoon of Wednesday July $20^{\text {th }}$ and Thursday July $21^{\text {st }}$ of 2016 . There were 27 participants the first day and 26 participants the second day. The participants were mostly the same people on both days, with an average ratio of $77 \%$ female and $23 \%$ male, most of which were in their 20s and mid-30s, a couple of participants in their 40s and the elder of the community (see figure 9 for pictures of the workshop). The workshop was delivered in Swahili and English, as the participants were not confident in their spoken English proficiency, regardless of being able to understand it. The responses were discussed and written down in a combination of Swahili and English. All the tables reported in this paper are only in English.

The comments shown in the tables in the following subsections are a transcript of the comments written on both days of the workshop on paper charts tapped at the front of the room where the workshop took place. The comments were initially expressed by a participant, and other participants were encouraged to agree/disagree and come to a consensus of their collective thinking. After agreeing on a sentence to be written, by simple majority, the facilitators took note of those comments on the charts represented in tables 3 and 5. The assessment of local flood protection in table 5 was carried out by two of the participants, following the same methodology presented previously.

\section{1) Setting Definitions}

The participants co-developed the definitions based on their perceptions and day-to-day experiences. Table 2 shows the agreed meanings for each corner of the assets pentagon and Appendix A shows the agreed meanings for the rating of each asset.

Table 2. Agreed meaning of each resource.

\begin{tabular}{c|l} 
Capital & \multicolumn{1}{|c}{ Meaning } \\
\hline Human & Our ability / capability to work \\
\hline Natural & Free things we have obtained from God \\
\hline Financial & Money / financial abilities; credit-worthiness and ability to invest \\
\hline Physical & Things we can see with our eyes that we've built \\
\hline Social & Ability to interact / Unity in working together (groups, communities, etc.)
\end{tabular}




\section{2) Initial Rating: Their Current Situation}

According to the definitions agreed upon, the participants rated their current situation as shown in table 3 . The plotted pentagon can be seen and compared with the results of the other scenarios in figure 8 .

Table 3. Transcription of the rating of the current situation and comments.

\begin{tabular}{c|c|l} 
Capital & Ranking & \multicolumn{1}{c}{ Comments } \\
\hline Human & 4 & A few are ill and can't go to work. \\
\hline Natural & 3 & $\begin{array}{l}\text { They have resources like land, soil, rocks and the river. } \\
\text { Give the river as an example: available but in bad conditions. }\end{array}$ \\
\hline Financial & 2 & The majority can afford to buy clothes, food and pay rent. \\
\hline Physical & 2 & $\begin{array}{l}\text { The infrastructure (examples: toilet, drains, stima) is in bad } \\
\text { condition but being used. }\end{array}$ \\
\hline Social & 3 & A few cooperate in community meetings
\end{tabular}

3) Voting for Interventions

Local drainage improvement was the intervention most voted for, with 21 votes in total, followed by local flood protection, which got 11 votes (see table 4). There was only one void vote, which contained only one sticker, and therefore it was not taken into consideration.

Table 4. List of infrastructural interventions and their corresponding vote. Highlighted in grey are the interventions with the most votes.

\begin{tabular}{ll|c}
\multicolumn{1}{|c|}{ Infrastructure } & Votes \\
\hline 1. & Local drainage improvement & 21 \\
2. & Local river protection & 2 \\
3. & Water point & 3 \\
4. & Local solid waste management & 2 \\
5. & Toilet block & 5 \\
6. & Local sewer improvement & 1 \\
7. & Local flood protection & 11 \\
8. Better access to bridge & 0 \\
9. Improvement of local pathways & 1 \\
\hline \multicolumn{2}{r}{ Total votes } & $46(23$ people $)$ \\
\hline & Void votes & 1
\end{tabular}




\section{4) Rating of Interventions: In Current Scenario}

The participants rated the interventions according to the definitions agreed upon. Table 5 includes the comments made by the participants at the time of the rating, expressing the reasons behind these ratings.

The combined resulting pentagons of each intervention can be seen in figure 8 .

Table 5. Comparison of the rankings of each scenario.

\begin{tabular}{|c|c|c|c|c|}
\hline & \multicolumn{2}{|c|}{ Local drainage improvement } & \multicolumn{2}{|c|}{ Local flood protection (gabions) } \\
\hline Capital & Ranking & Comments & $\begin{array}{c}\text { Rankin } \\
\text { g }\end{array}$ & Comments \\
\hline Human & 5 & $\begin{array}{l}\text { Everyone will be healthy, if we } \\
\text { continue to clean it and maintain } \\
\text { it }\end{array}$ & 4 & $\begin{array}{l}\text { Reduce risk of diseases outbreak } \\
\text { Reduce accidents of drowning } \\
\text { on children }\end{array}$ \\
\hline Natural & 4 & $\begin{array}{l}\text { The amount of pollution that will } \\
\text { reach the river will reduce } \\
\text { The environment would improve } \\
\text { because we won't have solid } \\
\text { waste dragged down into the } \\
\text { rivers during flooding or garbage } \\
\text { clogging the drains }\end{array}$ & 4 & $\begin{array}{l}\text { Prevention of soil erosion } \\
\text { (which can be used for } \\
\text { construction) } \\
\text { Improve surrounding and } \\
\text { quality of open spaces and can } \\
\text { be used as playground children } \\
\text { sunbathing }\end{array}$ \\
\hline Financial & 3.5 & $\begin{array}{l}\text { We can save up money by not } \\
\text { taking kids to clinics and buying } \\
\text { medicines that often, but we can } \\
\text { on only have a small business; } \\
\text { we won't have enough money } \\
\text { for a big business }\end{array}$ & 3.5 & $\begin{array}{l}\text { After improving, the area can } \\
\text { attract new business } \\
\text { Loss properties will be a gone } \\
\text { story } \\
\text { Saving money because the } \\
\text { regular paths we walk can still } \\
\text { be used during rainy season }\end{array}$ \\
\hline Physical & 3 & $\begin{array}{l}\text { We don't have all the } \\
\text { infrastructure but we will keep } \\
\text { and maintain the ones we have } \\
\text { If drains are improved, water } \\
\text { will not enter their houses and } \\
\text { destroy them and/or wash their } \\
\text { assets away }\end{array}$ & 3 & $\begin{array}{l}\text { Ensure no structures are } \\
\text { destroyed by flooding } \\
\text { Prevent loss of property and } \\
\text { houses } \\
\text { The little physical resources } \\
\text { they have will remain in good } \\
\text { condition }\end{array}$ \\
\hline Social & 4 & $\begin{array}{l}\text { Many will know each other but } \\
\text { not everyone will cooperate in } \\
\text { cleaning the drain } \\
\text { There is a need to develop a } \\
\text { waste management strategy }\end{array}$ & 4 & $\begin{array}{l}\text { Improve dignity of people living } \\
\text { in Andolo, as they won't be } \\
\text { labelled as those that live in the } \\
\text { flood zone } \\
\text { Tenant turnover, empty rooms } \\
\text { will be few, rent could increase }\end{array}$ \\
\hline Maintenance & Medium & $\begin{array}{l}\text { Maintaining will not be hard nor } \\
\text { easy. A section of people will be } \\
\text { cleaning up the drains, and } \\
\text { another section of people will be } \\
\text { dirtying them up } \\
\text { Maintenance of the drainage will } \\
\text { involve waste management and }\end{array}$ & Medium & $\begin{array}{l}\text { The construction of gabions is } \\
\text { expensive and requires a lot of } \\
\text { manpower, making it difficult } \\
\text { It is difficult to get all the people } \\
\text { to co-operate in flood protection } \\
\text { maintenance }\end{array}$ \\
\hline
\end{tabular}




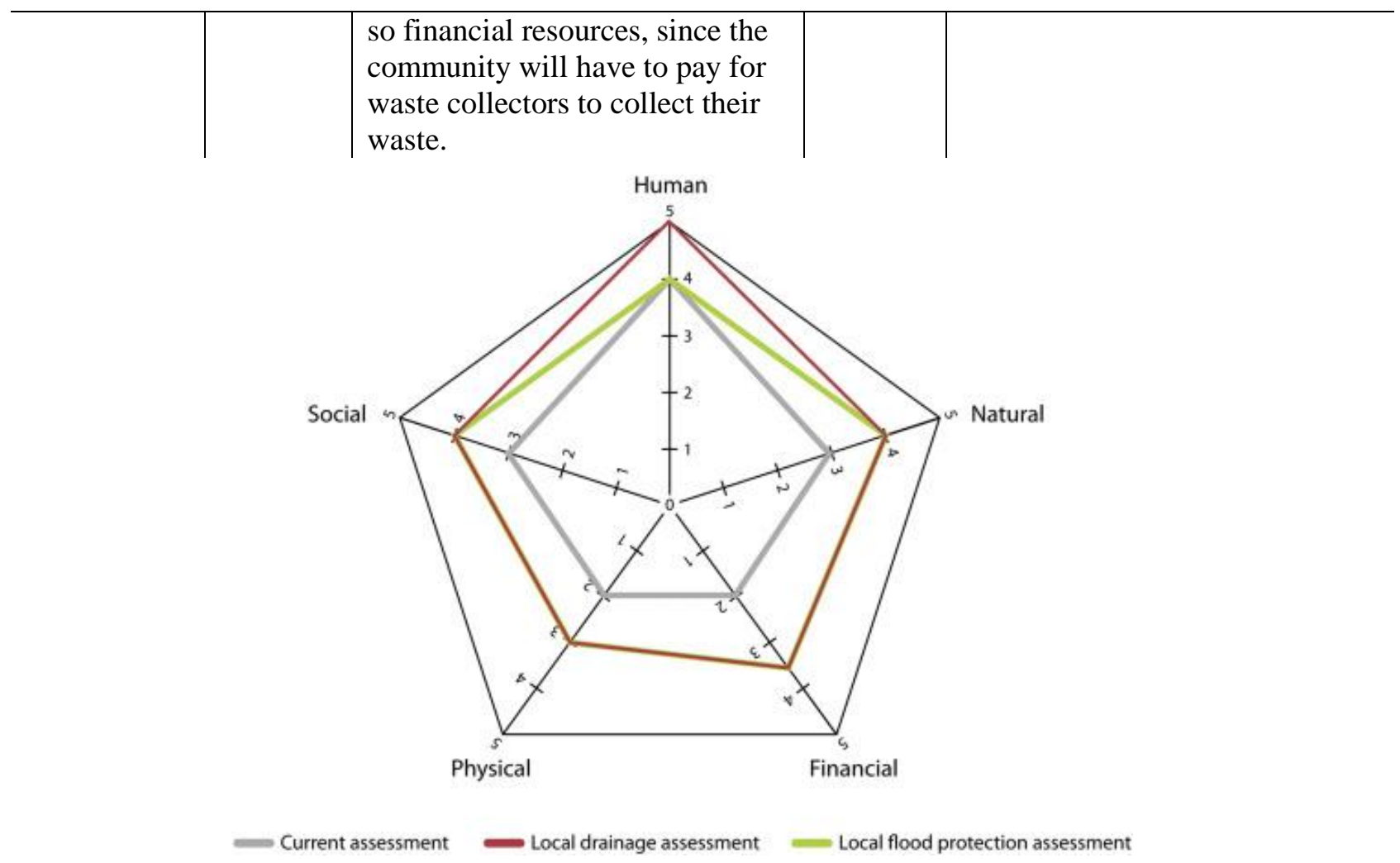

Figure 8. Combined results of the plotted assessments of current situation, local drainage improvement and local flood protection.

5) Final Comparisons and Review.

After analysing all the plotted polygons by showing them next to each other (see figure 9), the participants chose local drainage improvement as the intervention of their preference.
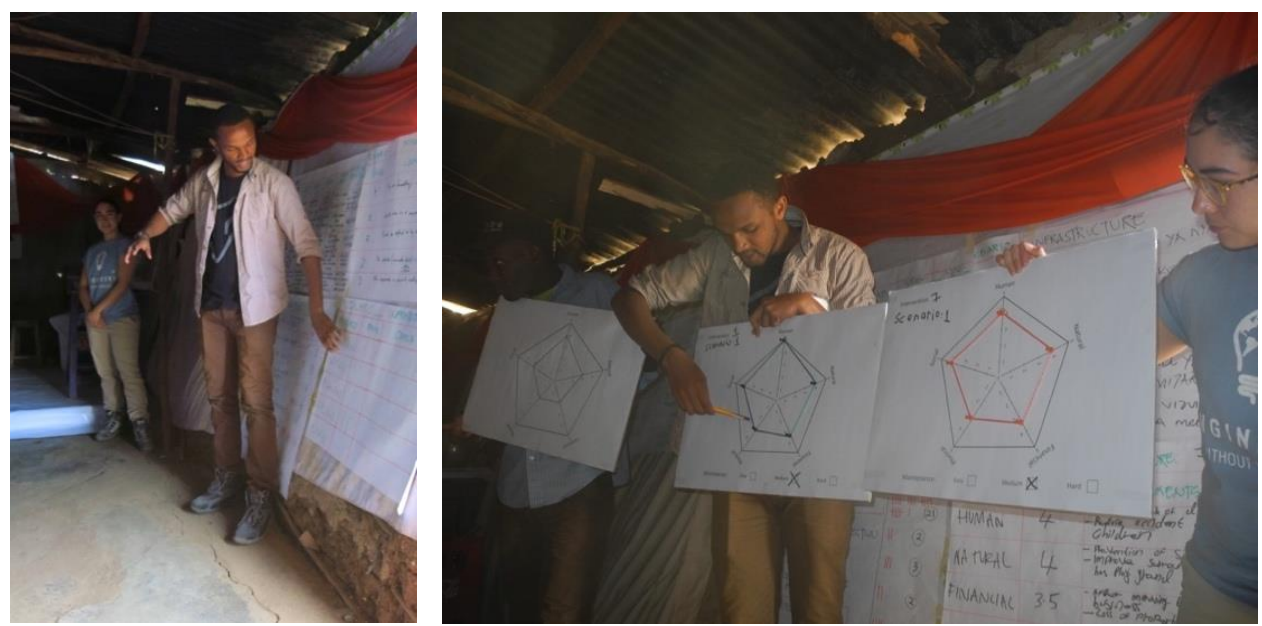

Figure 9. Facilitators at the workshop on day 2. (Photo by Pascal Kipkemboi). 


\section{Discussion}

The workshop proposed on this paper was an approach to develop a participatory method to create ownership of a project's decision making process while assisting participants to make informed decisions. Participation was at the core of the workshop and it proved successful in achieving high levels of engagement from the participants. Projects which prove successful in engaging communities to participate are likely to achieve more positive results, such as increased responsiveness to people's needs, and enhancing the capacity of communities to perform self-initiated projects in the future (Mulligan et al, 2011; Mansuri and Rao, 2004). Additionally, effective participation in community development projects has the potential to create agency and voice for communities, as well as to reverse traditional power relations (Mulligan et al, 2011).

The assets component of the SLF was an easy visual system for evaluation for the participants of this specific workshop, as it removed the need for high levels of literacy and numeracy (Anyaegbunam et al, 2004), making comparisons easier and facilitating the assessment of impacts. It further provided insights on how the participants viewed and valued the assets they possess, allowing them to appreciate, measure and acknowledge them. Negotiating the definitions of what a sustainable livelihood meant among participants (Scoones, 1998), in this case the different meanings they placed on their assets, proved to be a positive outcome in this workshop. Moreover, making the participants define the SLF's terms was helpful in creating ownership of the exercises (Mulligan et al., 2011). It was an interactive and iterative process which helped in raising their enthusiasm as well as to possibly placing new values into what they currently possess.

Documenting the process of decision making while the rating was taking place was useful to observe the nuanced ratings and the allocation of points between the two evaluated interventions. While both interventions were rated similarly, the reasons for each were different. There were two main topics highlighted by this process: health improvement, if local drainage improvement was carried out, and loss of property, if local flood protection was in place. Drawing comparisons between the ratings of both interventions was useful for showing the link between the research findings carried out by KDI with the daily experiences of the participants. FSP can be a useful tool for linking the formal and the informal economies by highlighting seemingly intangible assets and creative capacities that tend to remain invisible in the formal arena (Gollen et al., 2012). This can be useful to address complex challenges characterised by the absence of one-dimensional solutions (ibid), and in the case of this workshop, this benefited the process of informing about the different solutions to mitigate flooding. Involvement in community meetings and 
decision making processes therefore led the participants to choose critical infrastructure solutions to mitigate the effects of flooding.

It was interesting to note the participants finding gaps in the rating system and allocating half points to some of the ratings. This could have possibly been prevented with a more thorough guidance, although it is arguable if this measure could have been perceived as imposed. It could also be interpreted as a product of participants seeking compromise with each other, which can in turn be argued to be a reflection of the participatory nature of the workshop. Additionally, the assessment of scenarios was useful to reflect upon maintenance of infrastructure. This made the participants recognise that without maintenance and their attention to the project, there would be no improvement of their conditions, regardless of the intervention that were to be carried out. The workshop provided a platform for participants to discuss maintenance related challenges thereby ensuring longer-term sustainability of their infrastructure.

The workshop was useful for starting a conversation on infrastructure interventions and the needs of the area in which Andolo is based, helping in the prioritisation process of the wider Andolo community (Harper, personal communication, January 19, 2017). After the completion of the workshops, the participants informed other members community about its contents, disseminating the knowledge they gathered through the activities that were carried out (Harper, personal communication, January 19, 2017). The exercise was helpful in bringing other people from Andolo community together to discuss factors that influence their experiences, raise awareness and discover critical considerations for infrastructure interventions. The workshop facilitated discussion about technical issues within an audience with limited literacy. It served as a guide to develop a thought process that changed the focus from immediate needs to medium and longerterm needs (Lindgren \& Banhold, 2003), specifically through the use of FSP exercises, as the perceived longer-term efficacy of those solutions was explored through discussions on who should maintain the services and the need for participation for maintenance.

\subsection{Limitations and challenges}

The biggest limitation encountered during the delivery of this workshop was the delivery time; translation of terms and explanation of ideas took longer than anticipated, as time for this was not considered while designing the workshop plan. Furthermore, the activities proposed in this methodology are sequential and all the steps need to be understood to move forward in the workshop plan. An unengaged audience therefore could find it very hard to follow all the exercises and produce any outcome. Both FSP and SLF have been criticised for being time consuming (Morse et al., 2009; Scearce \& Fulton, 2004; Chermack et al., 2001); 
this workshop confirmed these criticisms on both tools, despite both methodologies being tailored for shorter timeframes. To apply this methodology, it is recommended to consider time allocation and availability to consider the community member's time. It is imperative to understand community dynamics to assess the suitability of this workshop within that context.

Another drawback was the uneven gender ratio of the attending participants. The majority of the people that attended the short notice call for participants were female residents, most of which attended both days. This could be due to the proposed time in which the workshop took place, which coincided with working hours. It is questionable if their opinions were representative of the community of Andolo- especially of those who would later be involved in maintenance- , and how different the results would be had there been a more balanced gender and age ratio. It is further uncertain if the concerns and opinions of all the participants were heard, regardless of the facilitators prompting for the participation of all the attendants. This however had no impact in the compliance of the wider community to carry out the infrastructure intervention selected at the end of the workshop for construction. It is worth noting that a follow up meeting was held to inform other members of the community of the results of this workshop and announce the construction of the intervention.

In terms of facilitation, training is needed to understand what both FSP as well as SLF encompass. It is of upmost importance that the facilitators delivering the activities understand the process and aim of both tools to obtain successful outcomes. In the case of this workshop, one of the facilitators was part of KDI, and was more engaged and informed about the area and the community, as well as able to speak the local language. The other facilitator was in charge of the design of the workshop and had a deeper understanding of the frameworks used, but was not acquainted the community nor the area. It is possible that this combination assisted in having a more nuanced understanding of the participants, while allowing to keep focus on the achieving the objectives of the workshop. It would have been interesting to conduct further research on the role the facilitators played in terms of achieving the outcomes of the workshop (Harvey et al., 2002), however that fell outside of the scope of the study and was not further assessed.

The participants showed creativity and resourcefulness in finding resources, as well as a positive attitude towards what they have in terms of all the assets discussed throughout this work. Their will to improve their situation, with whichever resources they had at hand, and their desire for respect and honourability were partially shown by their rating and subsequent comments. This however, may play a role in hampering them from assessing and scoring more impartially their livelihoods and assets, which in change can lead to providing overoptimistic comments like the ones seen on the tables. In addition to possibly wanting to 
conceal their lack of resources and maintain their dignity by reducing the likelihood of being negatively judged by outsiders.

It can be debated whether the application of this workshop would be equally successful in a different setting. The workshop needs further testing in order to gather broader conclusions about its effectiveness, and there is room for improvement for a more impartial mode of assessment. Its strength, however, relies on its codesign, access to information and open process of common definitions, which can be adapted in different contexts to more suitable ones.

\section{Conclusions}

The methodology proposed in this paper is an approach to public engagement to achieve informed decisionmaking in the co-production of public spaces, based in adapting the assets component of the Sustainable Livelihoods Framework - which offers a comprehensive visual rating system - to assess Future Scenarios. The workshop was useful in understanding how the residents of the community valued their assets and perceived the changes that project interventions could potentially bring to their livelihoods. It also helped the residents engage with a non-governmental organisation (in this case KDI), participate and commit in the exercises and understand the processes of different methodologies of community engagement. Furthermore, the process made the residents of Andolo community, especially those that participated in the workshop, understand the different intersections of their livelihoods and have a broader understanding of the relationships among these intersections (DFID, 1999a). This understanding helped in initiating conversations about critical infrastructure and prioritisation of interventions for mitigating immediate risks (Harper, personal communication, January 19, 2017). In addition, the workshop enabled the residents to recognise the need and value of maintenance of infrastructure (Mulligan et al., 2011), and there is anecdotal evidence to suggest higher levels of engagement from the community in these issues (Harper, personal communication, January 19, 2017). However, it would be difficult to tie these outcomes to the workshop alone, since it was part of a broader and ongoing engagement process with the community of Andolo.

Andolo is an extreme case and one of the most neglected areas in Kibera (Wandera, 2016). Members of community of Andolo were excited to take action in improving their living conditions, which worked in favour towards attendees' turnout and participation in the workshop activities. This motivation could also be linked to the ongoing engagement that KDI holds with the wider community of Kibera. In the specific case of Andolo, the workshop was a contributing factor in bringing the community closer, which in turn 
assisted the later formation of a Community Based Organisation. Through this workshop, it was possible to co-produce and agree on a public space project to be carried out in the neighbouring area.

The workshop was successful in raising awareness within the community of Andolo about the need of a drainage plan for the area before aiming to deliver any other type of infrastructure intervention, given the severity of the floods affecting that specific area. Both infrastructure interventions selected by the participants in the workshop had a focus on time saving, enhancing mobility, livelihood creation and dignity. Typically, infrastructure solutions in informal settlements have resulted in positive impact (Parikh et al., 2015) and residents perceive infrastructure services to be a priority (Parikh et al., 2012). There is scope to build on this methodology further, by testing the decision making tool in other sites and its linking the outcomes to longer term flooding adaptation measures for informal settlement communities. The assetbased approach would ensure that the co-selected infrastructure intervention would reduce vulnerability and enhance assets for local communities.

\section{References}

Adato, M. \& Meinzen-Dick, R. (2002). Assessing the Impact of Agricultural Research on Poverty Using the Sustainable Livelihoods Framework. FCND Discussion Paper 128, EPTD Discussion Paper 89. US: International Food Policy Research Institute (IFPRI).

Adaptation at Scale in Semi-Arid Regions (ASSAR). (2017). ASSAR: What/Where, [online]. South Africa: University of Cape Town. Available at: http://www.assar.uct.ac.za/about/about_ASSAR_project [Accessed 10 April 2017].

Advanced Training Program on Humanitarian Action (ATHA). (2014). Sustainable Livelihoods Framework, [online]. Available at: http://www.atha.se/content/sustainable-livelihoods-framework [Accessed 15 July 2016].

Anyaegbunam, C.; Mefalopulos, P. \& Moetsabi, T. (2004). Participatory Rural Communication Appraisal: Starting with the People: A Handbook, 2nd ed. Food and Agriculture Organzation of the United Nations, Rome, 160p.

BuroHappold Engineering. (2017a). Reducing Health Risks For An Entire Township: Kibera Toolkit For Flood Risk Reduction Nairobi, Kenya, [online]. Available at: https://www.burohappold.com/wpcontent/uploads/2017/08/Kibera-Toolkit-for-Flood-Risk-Reduction.pdf [Accessed 7 June 2018].

BuroHappold Engineering. (2017b). Kibera Toolkit for Flood Risk Reduction, [online]. BuroHappold Engineering. Available at: http://www.burohappold.com/projects/kibera-toolkit-flood-risk-reduction/ [Accessed 15 May 2017]. Calthorpe Associates. (2011). Rapid Fire Model: Technical Summary, Model Version 2.0, [online]. Available at: http://www.sgc.ca.gov/pdf/Rapid_Fire_V_2_0_Tech_Summary.pdf [Accessed 25 August 2016].

Carney, D., Drinkwater, M., Rusinow, T., Neefjes, K., Wanmali, S., \& Singh, N. (1999). Livelihoods Approaches Compared: A brief comparison of the livelihoods approaches of the UK Department for International Development (DFID), CARE, Oxfam and the United Nations Development Programme (UNDP). Department for International Development (DFID).

Centro Mario Molina (CMM). (2014). Ciudades: Merida, Urban Growth Scenarios for Sustainable Development. Centro Mario Molina, [online]. Available at: http://centromariomolina.org/english/wpcontent/uploads/2014/08/1.-Ciudades-Merida-2014-reporte_eng_fin.pdf [Accessed 25 August 2016]. 
Centro Mario Molina (CMM). (2015). Urban Planning Scenarios: Mexico City Metropolitan Area. Centro Mario Molina, [online]. Available at: http://centromariomolina.org/english/wp-content/uploads/2015/11/ResumenRF en.pdf [Accessed 25 August 2016].

Chambers, R. \& Conway, G. R. (1991). Sustainable Rural Livelihoods: Practical Concepts for the 21st Century. Institute of Development Studies (IDS) Discussion Paper 296. Available at: https://www.ids.ac.uk/files/Dp296.pdf [Accessed 16 August 2016].

Chaudhuri, S. (2013). Living at the Edge: A Socio-economic Profile of Kolkata's Poor. South Asian Survey, 20(1), pp. $44-58$.

Chermack, T.J.; Lynham, S.A. \& Ruona, W.E.A. (2001). A Review of Scenario Planning Literature. Futures Research Quarterly Summer, pp. 7-31.

Cotton, A. \& Franceys, R. (1994). Infrastructure for the urban poor: Policy and planning issues. Cities, 11(1), pp. $15-24$.

Cronin, V. and Guthrie, P. (2011). Alternative approaches to slum upgrading in Kibera, Nairobi. Proceedings of the ICE - Urban Design and Planning, 164(2), pp.129-139.

Dakson, C. \& Binns, T. (2010). Culture, tradition and sustainable rural livelihoods: exploring the culturedevelopment interface in Kandy, Sri Lanka. Community Development Journal, 45(4), pp.494-517.

Davidson, C.H., Johnson, C., Lizarralde, G., Dikmen, N. \& Sliwinski, A. (2007). Truths and myths about community participation in post-disaster housing projects. Habitat International, 31(1), pp. 100-115.

Department for International Development (DFID). (1999a). Key Sheets for Sustainable Livelihoods: Overview, Introduction, [online]. Available at: https://www.odi.org/sites/odi.org.uk/files/odi-assets/publications-opinionfiles/3219.pdf [Accessed 15 July 2016].

Department for International Development (DFID). (1999b). Sustainable Livelihoods Guidance Sheets: Framework, Section 2, [online]. Available at: http://www.eldis.org/vfile/upload/1/document/0901/section2.pdf [Last accessed 13 June 2018].

Dimanin, P. (2012). Exploring livelihoods of the urban poor in Kampala, Uganda: An institutional, community, and household contextual analysis. Action Against Hunger, [online]. Available at: http://www.actionagainsthunger.org/sites/default/files/publications/ACF_Uganda_Kampala_Urban_Study2012.pdf [Accessed 2 August 2017].

Dominguez, D.; Truffer, B. \& Gujer, W. (2011). Tackling uncertainty in infrastructure sectors through strategic planning: the contribution of discursive approaches in the urban water sector. Water Policy, 13(3), pp. 299-316

Dong, C.; Shoups, G. \& van de Giesen, N. (2013). Scenario development for water resource planning and management: a review. Technological Forecasting and Social Change, 80(4), pp. 749-761.

Donovan, K. (2012). Seeing Like a Slum: Towards Open, Deliberative Development. Georgetown Journal of International Affairs, 13(1), pp. 97-104.

Farrington, J., Ramasut, T. \& Walker, J. (2002). Sustainable Livelihoods Approaches in Urban Areas: General Lessons, with Illustrations from Indian Cases. Working Paper 162, UK: Overseas Development Institute, 60 pp.

Foresight for Development. (2017). Africa Environment Outlook - Past, Present and Future Perspectives, [online]. Available at: http://www.foresightfordevelopment.org/sobipro/55/91-africa-environment-outlook-past-presentand-future-perspectives [Accessed 5 June 2017].

Forum for the Future. (2013). Reimagining the Future of Informality: Scenarios from the Global South, [online]. Analysis Report. Available at:

https://www.forumforthefuture.org/sites/default/files/project/downloads/reimagining-future-informalityicdscenario-analysis-report.pdf [Accessed 10 April 2017].

Gollen, M.A., Hinze, G. \& Wong, T. (2012). Scenario planning on the future of intellectual property: Literature review and implications for human development. In: Wong, T., ed. Intellectual Property and Human Development: Current Trends and Future Scenarios. UK: Cambridge University Press, pp. 329-365. 
GRID Arendal. (2017). Africa Environment Outlook - Past, present and future perspectives [online]. Available at: https://www.grida.no/publications/80 [Accessed 5 June 2017].

Guillet, C. 8 May 2014. Why is slum upgrading so complicated? Development Governance and Dreams for Kibera. Poasana, [online]. Available at: https://carolineguillet.com/2014/05/08/why-is-slum-upgrading-so-complicateddevelopment-governance-and-dreams-for-kibera/ [Accessed 1 August 2016].

Hagans, C. (2013). Livelihoods, land-use \& public transport: Opportunities for poverty reduction and risks of splintering urbanism in Nairobi’s Spatial Plans. DPU Working Papers 159. UK: Development Planning Unit, UCL.

Hahn, M.B., Riederer, A.M. \& Foster, S.O. (2009). The Livelihood Vulnerability Index: A pragmatic approach to assessing risks from climate variability and change-A case study in Mozambique. Global Environmental Change, 19, pp. 74-88.

Harper, J. (2016, June 26). Personal interview KDI.

Harper, J. (2017, January 19). Personal interview KDI.

Harvey, G.; Loftus-Hills, A.; Rycroft-Malone, J.; Titchen, A.; Kitson, A.M.; Cormack, B. \& Seers, K. (2002). Getting evidence into practice: the role and function of facilitation. Journal Of Advanced Nursing, 37(6), pp. $577-58$

Hossain, S. (2005). Poverty, Household Strategies and Coping with Urban Life: Examining 'Livelihood Framework' in Dhaka City, Bangladesh. Bangladesh e-Journal of Sociology, 2(1). Available at:

http://www.bangladeshsociology.org/BEJS\%20-\%202.1.1-\%20Shahadat.pdf [Accessed 2 August 2017].

Ideo. (2016). The Flood Line: Improving awareness and reducing the risk of disaster in Kibera, [online]. Available at: https://www.ideo.org/project/kounkuey-design-initiative [Accessed 7 June 2018].

International Federation of Red Cross and Red Crescent Societies (IFRC). (2016). What is a livelihood? [online]. Available at: http://www.ifrc.org/en/what-we-do/disaster-management/from-crisis-to-recovery/what-is-alivelihood/ [Accessed 16 August 2016].

Juma, B. (2017, May). Flood Inundation, Risk and Impact in Kibera Slums of Nairobi- Kenya. Multi-Hazard Early Warning Conference and Global Platform for Disaster Risk Reduction, Cancún, México

Kahane, A. (1996). The Month Fleur Scenarios: What will South Africa look like in the year 2002?. Deeper News, 7(1). US: Global Business Network.

Kounkuey Design Initiative (KDI). (2015). Building Urban Flood Resilience: Integrating Community Perspectives in Kibera, [online]. Kounkuey Design Initiative. Available at: http://blog.kounkuey.org/wpcontent/uploads/2015/03/150111-Urban-Flooding-Project-Overview.pdf [Accessed 13 July 2016].

Kounkuey Design Initiative (KDI). (2016). Kounkuey Design Initiative, [online]. Available at: http://www.kounkuey.org [Accessed 11 July 2016].

Kounkuey Design Initiative (KDI). (2016, June 26). Internal report of Andolo.

Latif, M.; Semenov, V.A. \& Park, W. (2015). Super El Niños in response to global warming in a climate model. Climatic Change, 132, pp. 489-500

Lee, M.H. (2008). Tourism and Sustainable Livelihoods: the case of Taiwan. Third World Quarterly, 29(5), pp. 961978.

Leting, M. (2017). Nyumba Kumi Strategy of Community Policing And Its Impact on Curbing Crime; Empirical Assessment From Kenya. IOSR Journal Of Humanities And Social Science, 22(1), pp. 32-36.

Lienert, J.; Monstadt, J. \& Truffer, B. (2006). Future scenarios for a sustainable water sector: a case study from Switzerland. Environmental Science \& Technology, 40(2), pp. 436-442.

Lienert, J., Scholten, L., Egger, C. \& Maurer, M. (2014). Structured decision-making for sustainable water infrastructure planning and four future scenarios. EURO Journal on Decision Processes, 125, pp. 107-140. 
Lindgren, M. \& Banhold, H. (2003). Scenario Planning: The link between future and strategy. US: Palgrave Macmillan.

Majale, M. (2008). Employment creation through participatory urban planning and slum upgrading: The case of Kitale, Kenya. Habitat International, 32(2), pp. 270-282.

Mansuri, G. \& Rao, V. (2004). Community-Based and -Driven Development: A Critical Review. The World Bank Research Observer, 9(1), pp. 1-39.

Map Kibera Project. (2010). Map Kibera Project, [online]. Available at: http://mapkiberaproject.yolasite.com/ [Accessed 31 July 2017].

Masanjala, W. (2007). The poverty-HIV/AIDS nexus in Africa: a livelihood approach. Social Science \& Medicine, 64(5), pp.1032-1041.

McSweeney, C., New, M., Lizcano, G. \& Lu, X. (2010). The UNDP Climate Change Country Profiles Improving the Accessibility of Observed and Projected Climate Information for Studies of Climate Change in Developing Countries. Bulletin of the American Meteorological Society, 91, p. 157-166.

Meikle, S., Ramasut, T. \& Walker, J. (2001). Sustainable Urban Livelihoods: Concepts and Implications for Policy. DPU Working Papers 112. UK: Development Planning Unit, UCL.

Meredith, T. and MacDonald, M., 2017. Community-supported slum-upgrading: Innovations from Kibera, Nairobi, Kenya. Habitat International, 60, pp.1-9.

Mersha, A. \& Van Laerhoven, F. (2016). A gender approach to understanding the differentiated impact of barriers to adaptation: responses to climate change in rural Ethiopia. Regional Environmental Change, 16(6), pp.1701-1713.

Mitra, S.; Mulligan, J.; Schilling, J.; Harper, J.; Vivekananda, J. \& And Krause, L. (2017) Developing risk or resilience? Effects of slum upgrading on the social contract and social cohesion in Kibera, Nairobi. Environment and Urbanization, 29(1), pp. 103-122

Morse, S., McNamara, N. \& Acholo, M, (2009). Sustainable Livelihood Approach: A critical analysis of theory and practice. Geographical Paper No. 189, p. 67. Available at:

https://www.reading.ac.uk/web/files/geographyandenvironmentalscience/GP189.pdf [Accessed 7 June 2017].

Mulligan, J.; Tompsett, A. \& Guthrie, P. (2011). An 'engineer-client' framework for participation in communityscale infrastructure projects. Engineering Sustainability, 164(ES1), pp. 35-47

Mulligan, J., Harper \& Ngobi, B. (2015). Building Urban Flood Resilience in Kibera: Consultation and Data Collection Methodology for the Building Urban Flood Resilience in Kibera project. Rev 01, [online]. p. 92. Available at:

http://www.kounkuey.org/150323\%20KDI\%20Urban\%20Flooding\%20Consultation\%20and\%20Data\%20Colle ction\%20Methodology\%20REV01.pdf [Accessed 20 June 2016].

Mulligan, J., Harper, J., Kipkemboi, P., Ngobi, B. \& Collins, A. (2017). Community-responsive adaptation to flooding in Kibera, Kenya. Proceedings of the Institution of Civil Engineers - Engineering Sustainability, 170(5), pp. 268-280.

Muthoni Kagiri, E. (2008). Using Sustainable Technology to Upgrade Sanitation. Case Study: Soweto East, Kibera. Thesis (MA), University of Jyväskylä.

Oppenheimer, M. (2016). Value of Scenarios. In Pivotal Countries, Alternate Futures: Scenario Planning for International Politics (pp. 1-21). New York: Oxford University Press. https://doi.org/10.1093/acprof:oso/9780199397099.001.0001

Orchard, S., Stringer, L. \& Quinn, C. Mangrove system dynamics in Southeast Asia: linking livelihoods and ecosystem services in Vietnam. Regional Environmental Change, 16(3), pp.865-879.

Orr, A. \& Mwale, B. (2001). Adapting to Adjustment: Smallholder Livelihood Strategies in Southern Malawi. World Development, 29(8), pp.1325-1343. 
Otieno Andhoga, W. \& Mavole, J. (2017). Influence of Nyumba Kumi Community Policing Initiative on Social Cohesion among Cosmopolitan Sub Locations in Nakuru County. International Journal of Social and Development Concerns, 1(6/12), pp. 65-76.

Pandey, R.. Jha, S.K., Alatalo, J.M., Archie, K.M. \& Gupta, A.K. (2017). Sustainable livelihood framework-based indicators for assessing climate change vulnerability and adaptation for Himalayan communities. Ecological Indicators, 79, pp. 338-346.

Page, S.J., Yeoman, I., Connell, J. \& Greenwood, C. (2010). Scenario planning as a tool to understand uncertainty in tourism: the example of transport and tourism in Scotland in 2025. Current Issues in Tourism, 138(2), pp. 99137.

Parikh, P., Parikh, H. \& McRobie, A. (2012). The role of infrastructure in improving human settlements. Proceedings of the Institution of Civil Engineers-Urban Design and Planning, 166(2), 101-118.

Parikh, P., Fu, K., Parikh, H., McRobie, A., \& George, G. (2015). Infrastructure Provision, Gender, and Poverty in Indian Slums. World Development, 66(C), 468-486.

Peterson, G.D.; Cumming, G.S. \& Carpenter, S.R. (2003). Scenario planning: a tool for conservation in an uncertain world. Conservation Biology, 17(2), pp. 358-366.

Qian, C., Sasaki, N., Jourdain, D., Kim, S.M. \& Shivakoti, P.G. (2017). Local livelihood under different governances of tourism development in China - A case study of Huangshan mountain area. Tourism Management, 61, pp. 221-233.

Reos Partners. (14 March 2010). Learning from Experience: The Mont Fleur Scenario Exercise. Reos Partners Blog, [online]. Available at: http://reospartners.com/learning-from-experience-the-mont-fleur-scenario-exercise/ [Accessed 5 June 2017].

Ringland, G. (1998). Scenario Planning: Managing for the Future. UK: John Wiley \& Sons, Ltd.

Rosen, J. 22 March 2013. Using Futures to Generate Innovations for the Informal City Dialogues. Next City, [online]. Available at: https://nextcity.org/informalcity/entry/using-futures-to-generate-innovations-for-theinformal-city-dialogues [Accessed 16 May 2017].

Roxburgh, C. November 2009. The use and abuse of scenarios. McKinsey \& Company, [online]. Available at: http://www.mckinsey.com/business-functions/strategy-and-corporate-finance/our-insights/the-use-and-abuse-ofscenarios [Accessed 16 August 2016].

Scearce, D. \& Fulton, K. (2004). What If? The Art of Scenario Thinking for Nonprofits. US: Global Business Network, O. 119.

Scoones, I. (1998). Sustainable Rural Livelihoods: A Framework for Analysis. IDS Working Paper 72.

Skilling, L. \& Rogers, C. (2017). Crime prevention and coping mechanisms in neighbourhoods: insights from Kibera, Nairobi. Crime Prevention and Community Safety, 19(2), pp. 103-121.

Swart, R.J.; Raskin, P. \& Robinson, J. (2004). The problem of the future: Sustainability science and scenario analysis. Global Environmental Change, 14(2), pp. 137-146.

Thorn, J.; Thornton, T.F. \& Helfgott, A. (2015). Autonomous adaptation to global environmental change in periurban settlements: Evidence of a growing culture of innovation and revitalisation in Mathare Valley Slums, Nairobi. Global Environmental Change, 31, pp. 121-131

Truffer, B.; Störmer, E.; Maurer, M. \& Ruef, A. (2010). Local strategic planning processes and sustainability transitions in infrastructure sectors. Environmental Policy and Governance, 20(4), pp. 258-269.

Umande Trust, Centre on Housing Rights and Evictions (COHRE) \& Hakijamii Trust. (2007). The Right to Water and Sanitation in Kibera, Nairobi, Kenya. Summary Version - An Action Research Report. Kenya: COHRE.

United Nations Environment Programme (UNEP). (2005). AEO for Youth: Africa Environment Outlook for Youth: Our Region - Our Life. Kenya: UNON Printshop, p. 106.

van Rijn, F., Burger, K. \& den Belder, E. (2012). Impact assessment in the Sustainable Livelihood Framework. Development in Practice, 22(7), pp. 1019-1035. 
Wack, P. (1985). Scenarios: Uncharted Waters Ahead. Harvard Business Review, 63(5), p. 73-89.

Wandera, A. O. 20 October 2016. Andolo - The Last Frontier In Kibera - KPSP10. KDI Blog, [online]. Available at: http://blog.kounkuey.org/2016/11/10/andolo-the-last-frontier-in-kibera-kpsp10/ [Accessed 10 April 2017].

Woolf, S., Twigg, J., Parikh, P., Karaoglou, A., \& Cheaib, T. (2016). Towards measurable resilience: A novel framework tool for the assessment of resilience levels in slums. International Journal of Disaster Risk Reduction, (19), 280-302. 
Appendix A. Agreed meaning of each rating (translated to English).

\begin{tabular}{|c|c|c|c|c|c|}
\hline $\begin{array}{l}\text { Capital } \\
\text { |Rating }\end{array}$ & Human & Natural & Financial & Physical & Social \\
\hline $\begin{array}{l}\text { Very } \\
\text { good } \\
(5)\end{array}$ & $\begin{array}{l}\text { Everyone is healthy and } \\
\text { can go to work }\end{array}$ & $\begin{array}{l}\text { All the resources are } \\
\text { readily available and of } \\
\text { very good quality }\end{array}$ & $\begin{array}{l}\text { We have all the financial } \\
\text { abilities: we can invest, } \\
\text { obtain a loan, do } \\
\text { business, pay for all } \\
\text { needs }\end{array}$ & $\begin{array}{l}\text { ALL the infrastructure } \\
\text { required is installed and } \\
\text { in very good condition }\end{array}$ & $\begin{array}{l}\text { We ALL know and like } \\
\text { each other. We ALL } \\
\text { cooperate together }\end{array}$ \\
\hline $\begin{array}{l}\text { Good } \\
(4)\end{array}$ & $\begin{array}{l}\text { A few are unhealthy and } \\
\text { can't go to work }\end{array}$ & $\begin{array}{l}\text { The resources are } \\
\text { available but of slightly } \\
\text { bad quality }\end{array}$ & $\begin{array}{l}\text { We cannot invest in large } \\
\text { businesses }\end{array}$ & $\begin{array}{l}\text { ALL infrastructure is } \\
\text { installed but in slightly } \\
\text { bad condition }\end{array}$ & $\begin{array}{l}\text { We ALL know each } \\
\text { other but A FEW of us } \\
\text { cooperate }\end{array}$ \\
\hline $\begin{array}{l}\text { Ok } \\
(3)\end{array}$ & $\begin{array}{l}\text { Half of the people are } \\
\text { healthy and can go to } \\
\text { work }\end{array}$ & $\begin{array}{l}\text { A few of the natural } \\
\text { resources are available } \\
\text { and of reasonable } \\
\text { quality }\end{array}$ & $\begin{array}{l}\text { Can pay for all your } \\
\text { needs but no savings }\end{array}$ & $\begin{array}{l}\text { SOME of the required } \\
\text { infrastructure is installed } \\
\text { and is in good condition }\end{array}$ & $\begin{array}{l}\text { A FEW of us know each } \\
\text { other and A FEW of us } \\
\text { co-operate }\end{array}$ \\
\hline $\begin{array}{l}\mathrm{Bad} \\
(2)\end{array}$ & $\begin{array}{l}\text { More than half of the } \\
\text { people are sick and can't } \\
\text { go to work }\end{array}$ & $\begin{array}{l}\text { The few available } \\
\text { resources are of bad } \\
\text { quality }\end{array}$ & $\begin{array}{l}\text { We have the ability to } \\
\text { pay for basic needs } \\
\text { ONLY }\end{array}$ & $\begin{array}{l}\text { SOME of the } \\
\text { infrastructure required } \\
\text { has been installed but it } \\
\text { is in a bad condition }\end{array}$ & $\begin{array}{l}\text { MOST of us know each } \\
\text { other but we DO NOT } \\
\text { cooperate }\end{array}$ \\
\hline $\begin{array}{l}\text { Very bad } \\
\text { (1) }\end{array}$ & $\begin{array}{l}\text { The majority of the } \\
\text { people are sick and can't } \\
\text { go to work }\end{array}$ & $\begin{array}{l}\text { The few available } \\
\text { resources are of very bad } \\
\text { quality }\end{array}$ & $\begin{array}{l}\text { We cannot pay for all } \\
\text { basic needs. Food ONLY }\end{array}$ & $\begin{array}{l}\text { VERY FEW of the } \\
\text { required infrastructure } \\
\text { has been installed and it } \\
\text { is still in a very bad } \\
\text { condition }\end{array}$ & $\begin{array}{l}\text { VERY FEW of us know } \\
\text { each other and we } \\
\text { CANNOT cooperate }\end{array}$ \\
\hline $\begin{array}{l}\text { Non- } \\
\text { existent } \\
(0)\end{array}$ & $\begin{array}{l}\text { Everyone is very sick and } \\
\text { can't go to work }\end{array}$ & $\begin{array}{l}\text { No resources are } \\
\text { available in Andolo }\end{array}$ & $\begin{array}{l}\text { We have no financial } \\
\text { ability }\end{array}$ & $\begin{array}{l}\text { There is absolutely no } \\
\text { infrastructure installed }\end{array}$ & $\begin{array}{l}\text { We DO NOT know each, } \\
\text { we DON'T like each } \\
\text { other, and hence we } \\
\text { CANNOT cooperate }\end{array}$ \\
\hline
\end{tabular}

